\title{
Etiologies of Liver Cytolysis in the Service of Hepato-Gastroenterology of the Gabriel Toure University Hospital
}

\author{
Hourouma Sow wife Coulibaly ${ }^{1}$, Kadiatou Doumbia wife Samaké1, \\ Moussa Younoussa Dicko1, Deborah Sanogo wife Sidibé2, Makan Siré Tounkara1, \\ Ousmane Diarra ${ }^{1}$, Anselme Konaté ${ }^{1}$, Moussa Tiemoko Diarra ${ }^{1}$, Moussa Youssoufa Maiga ${ }^{1}$ \\ ${ }^{1}$ Department of Hepato-Gastroenterology of the Gabriel Touré University Hospital Center, Bamako, Mali \\ ${ }^{2}$ Internal Medicine Department of the Point G University Hospital Center, Bamako, Mali \\ Email: sowhourouma@yahoo.fr
}

How to cite this paper: Coulibaly, H.S.w., Samaké, K.D.w., Dicko, M.Y., Sidibé, D.S.w., Tounkara, M.S., Diarra, O., Konaté, A., Diarra, M.T. and Maiga, M.Y. (2021) Etiologies of Liver Cytolysis in the Service of Hepato-Gastroenterology of the Gabriel Toure University Hospital. Open Journal of Gastroenterology, 11, 211-219.

https://doi.org/10.4236/ojgas.2021.1111022

Received: May 28, 2021

Accepted: October 31, 2021

Published: November 3, 2021

Copyright () 2021 by author(s) and Scientific Research Publishing Inc. This work is licensed under the Creative Commons Attribution International License (CC BY 4.0).

http://creativecommons.org/licenses/by/4.0/ (c) (i) Open Access

\section{Abstract}

Aggression to the liver by xenobiotic and endogenous agents essentially results in an increase in serum aminotransferases related to hepatic cytolysis, the diagnosis of which is not always easy due to the diversity of its causes. This was a cross-sectional study from April 2019 to March 2020 that took place in the Department of Hepato-gastroenterology of the Gabriel Touré University Hospital Center. This was a cross-sectional study from April 2019 to March 2020 which took place in the Hepato Gastroenterology department of the Gabriel Touré university hospital whose objective of which was to study the etiology of hepatic cytolysis. We included all patients with hepatic cytolysis resulting in increased aminotransferase alanine at a rate higher than the normal upper limit with or without an increase of aspartate aminotransferase. We collected 199/2800 patients who met our inclusion criteria, i.e., a frequency of $7.1 \%$. The mean age was 44.06 years \pm 16.4 years, the sex ratio was 1.73 . The most common clinical signs were jaundice, ascites, hepatomegaly, asthenia and anorexia. Biologically, chronic cytolysis was noted with a moderate elevation of aminotransferase alanine in $77.9 \%$ and a significant elevation in $15.5 \%$ of cases. HBs antigen ( $\mathrm{HBsAg}$ ) was positive in 80 patients (40.2\%) and anti-hepatitis $\mathrm{C}$ virus (HCV) antibody in 18 patients (9\%). Abdominal ultrasound was the first-line morphological examination and hepatomegaly alone or associated with splenomegaly was the most common abnormality. The main causes of acute cytolysis were viral hepatitis B, bile duct obstructions, drug-induced hepatitis and malaria while chronic cytolysis was mainly due to cirrhosis and hepatocellular carcinoma (HCC).
\end{abstract}




\section{Keywords}

Liver Cytolysis, Transaminases, Etiology, Mali

\section{Introduction}

The liver, the crossroads of most metabolisms, is subject to attack by many xenobiotic and endogenous agents. This aggression is essentially reflected by an increase in serum aminotransferases in connection with hepatic cytolysis. Thus, the etiological diagnosis of hepatic cytolysis is not always easy due to the diversity of its causes. It is, therefore, useful to determine the cause for appropriate management. Although alanine aminotransferase (ALAT) has narrower specificity for the liver, a predominance of aspartate aminotransferase (ASAT) may be observed in some situations. Although these enzymes expressed hepatocellular suffering, they do not always have a prognostic value.

On the other hand, if a value greater than 15 times the upper limit of normal $(15 \mathrm{~N})$ indicates acute cytolysis and a value less than 10 times the upper limit of normal $(10 \mathrm{~N})$ suggests chronic cytolysis, and among the two there is a gray area difficult to classify [1]. Another source of hepatic cytolysis must also be eliminated. In the United States, the prevalence of hepatic cytolysis has been reported at $7.9 \%$, of which $31 \%$ are closely linked to excessive alcohol consumption, or to viral hepatitis or iron overload and $69 \%$ are associated with a metabolic syndrome [2]. In two (2) French studies in blood donors, hepatic cytolysis was reported to be $0.5 \%$ and $5 \%$ respectively [3] [4]. In Mali, we did not find any studies on hepatic cytolysis, hence this study on their etiologies.

\section{Patients and Methods}

This was a cross-sectional study that took place from April 2, 2019 to March 31, 2020 in the hepato-gastroenterology department of the Gabriel Touré university hospital. Our inclusion criteria were:

- Patients with an increase in alanine aminotransferase alone beyond the upper normal limit;

- Patients with an increase in alanine aminotransferase beyond the upper normal limit associated with an increase in aspartate aminotransferase.

We excluded cases of cytolysis involving only aspartate aminotransferases.

All patients benefited from:

An interrogation which made it possible to research

- Socio-demographic data: age, sex, ethnicity, profession, residence;

- History: Alcoholism, blood transfusion, notion of taking hepatotoxic drugs, smoking, notion of liver disease, tattooing and scarification, or other pathologies;

- Signs of the disease: asthenia, anorexia, myalgia, arthralgia, abdominal pain, gastrointestinal bleeding. 
A complete physical examination that looked for signs of liver disease

- Jaundice with or without pruritus;

- Asterixis;

- Fetor hepaticus;

- Stellar Angioma;

- Purpura, petechiae;

- Palmar erythrosis;

- Splenomegaly;

- Hepatomegaly;

- Abdominal collateral venous circulation (CVC);

- Ascites;

- Dark urine;

- Discolored stools;

- Scratching lesions.

> Para-clinical examinations included

o Biological examinations: Determination of aminotransferases, alkaline phosphatases, Gamma glutamyl transferase, total and conjugated bilirubinemia, ferritinemia, prothrombin level, serological markers of viral hepatitis A, B, C, D, E: Anti-hepatitis virus antibodies A; HBs antigen, anti HBc antibody, anti hepatitis $\mathrm{C}$ virus antibody, anti hepatitis $\mathrm{D}$ virus antibody, anti hepatitis E virus antibody, alpha foeto-protein, anti mitochondria type 2 antibody, anti smooth muscle antibody, anti LKM1 antibody.

o Morphological examinations

- Abdominal ultrasound or abdominal computed tomography (CT) to assess the morphology of the liver, gall bladder and portal system;

- Chest X-ray to check for cardiomegaly or pneumonia;

- Electrocardiogram (ECG) to look for signs of right or global heart failure;

- Eso-gastro-duodenal fibroscopy looking for esophageal and/or cardiotuberosity varices, portal hypertensive gastropathy, ulcer, erosions, and antral vascular ectasia;

- Fine needle puncture for cytological study of the liver.

The information on the variables were obtained through individual survey forms and recorded on EPI Info 6.0. The texts and tables were produced using Microsoft Word 2013 software. The Chi-square statistical test was used to compare the results. The significance level was set at $\mathrm{p}<0.05$.

\section{Results}

At the end of this study, 199 patients were able to meet our inclusion criteria out of 2800 consultations, either a hospital frequency of $7.1 \%$.

The age groups of 26 - 35, 36 - 45, 46 - 55 were in the majority in the sample $(18.6 \%, 21.6 \%$ and $18.1 \%)$. Men were the majority in the sample, $63.3 \%$ with a sex ratio of 1.73 . Farmers and housewives were in the majority in $22.6 \%$ and $21.1 \%$ of the sample, respectively. Mainly asthenia and anorexia were the signs 
which motivated the consultation in the patients in respectively $94.9 \%$ and 83.4\% (Table 1). Fever and epistaxis was the least common at $0.5 \%$. Jaundice was the most common antecedent (24.1\% of cases). However, $24 \%$ of patients had no history. Jaundice, hepatomegaly and ascites were the most common physical signs in $44.2 \%, 27.6 \%$ and $26.1 \%$, respectively (Table 2). Discolored stools, collateral venous circulation and hepato-jugular reflux were the least frequent physical signs with $9 \%, 8 \%$ and $7.5 \%$ respectively. Aminotransferase alanine elevation $>1.5 \mathrm{~N}$ and $<10 \mathrm{~N}$ was observed in $77.9 \%$. An associated elevation of

Table 1. Frequency of signs that prompted the consultation in study patients.

\begin{tabular}{ccc}
\hline Signs & Effective & Percentage \% \\
\hline Asthenia & 189 & 94.9 \\
Anorexia & 166 & 83.4 \\
Abdominale pain & 72 & 36.1 \\
Dark urine & 70 & 35.2 \\
Vomiting & 45 & 22.6 \\
Pruritus & 25 & 12.5 \\
Discolored stools & 19 & 9.5 \\
Diarrhea & 11 & 5.5 \\
Arthralgia & 11 & 5.5 \\
Nausea & 7 & 3.5 \\
Myalgia & 2 & 1 \\
Fever & 1 & 0.5 \\
Epistaxis & 1 & 0.5 \\
\hline
\end{tabular}

Table 2. Distribution of physical signs found in the patients in the study.

\begin{tabular}{ccc}
\hline Physical signs & Effective & Percentage \% \\
\hline Jaundice & $\mathbf{8 8}$ & 44.2 \\
Hepatomégaly & 55 & 27.6 \\
Ascites & 52 & 26.1 \\
Hyperthermia & 40 & 20.1 \\
edema of the lower limbs & 39 & 19.6 \\
Dark urine & 37 & 18.6 \\
Tachycardia & 37 & 18.6 \\
Hépatic Encéphalopathy & 35 & 17.6 \\
Scratching lesions + Pruritus & 21 & 10.5 \\
Decolored stools & 18 & 9 \\
collateral venous circulation & 16 & 8 \\
hepato-jugular reflux & 15 & 7.5 \\
\hline
\end{tabular}


aminotransferase aspartate was found in 152 cases (51.2\%). The frequency of HBs antigen carriage was $40.2 \%$ in patients. Anemia (microcytic, hypochromic) was the most common abnormality on the blood count. An elevation of transaminases $>1.5 \mathrm{~N}$ and $<10 \mathrm{~N}$ related to HBsAg and anti-HCV antibody was predominant in $77.5 \%$ and $100 \%$ of cases, respectively. Of 199 patients, 184 were able to perform an abdominal ultrasound of which 25 had a normal result and 159 had an abnormality. Homogeneous hepatomegaly alone or associated with splenomegaly was found in $52.7 \%$ of cases. Ultrasound was normal in $13.6 \%$ of patients. Of 199 patients, 47 underwent abdominal-pelvic CT scan, all of which had an abnormal result. Hepatocellulllary carcinoma and cirrhosis were common at $61.7 \%$ and $23.4 \%$. Endoscopy was performed in 101/199 of our patients and normal in $22.8 \%$ of patients. Esophageal varices and portal hypertensive gastropathy were the most common endoscopic signs, at $26.8 \%$ and $18.8 \%$, respectively. Viral hepatitis and complications (Hepatocellulllary carcinoma and cirrhosis) dominated the etiology of liver cytolysis (Table 3). Chronic cytolysis was significantly observed during Hepatocellulllary carcinoma andcirrhosis ( $\mathrm{p}=$ $0.0008,0.00003$ ) while acute cytolysis was significantly encountered during viral, drug, bile duct obstructions and malaria ( $\mathrm{p}=0.00006,0.00003,0.00000001$ and 0.0282) (Table 4).

Table 3. Distribution of etiologies found in patients.

\begin{tabular}{|c|c|c|}
\hline Etiologies & Effectif & Pourcentage $\%$ \\
\hline Cirrhosis & 53 & 26.6 \\
\hline Hepatocellulllary carcinoma & 40 & 20.1 \\
\hline Chronic viral hepatitis & 38 & 19.1 \\
\hline AIDS & 09 & 4.5 \\
\hline Drug-induced hepatitis & 10 & 5 \\
\hline Hepatic abscess & 05 & 2.5 \\
\hline Tancreatic tumor & 05 & 2.5 \\
\hline Peritoneal tuberculosus & 07 & 3.5 \\
\hline Lithiasis cholecystitis & 07 & 3.5 \\
\hline Malaria & 06 & 03 \\
\hline Liver metastases & 03 & 1.5 \\
\hline Alcoholic hepatitis & 03 & 1.5 \\
\hline Heart liver & 02 & 1 \\
\hline Fatty liver & 06 & 3 \\
\hline Hyperthyroidism & 01 & 0.5 \\
\hline Hydro cholecyst & 01 & 0.5 \\
\hline Angiocholitis & 01 & 0.5 \\
\hline Cholangiocarcinoma & 01 & 0.5 \\
\hline Hellp syndrome & 01 & 0.5 \\
\hline
\end{tabular}


Table 4. Relationship between the etiologies and elevation values of ALT.

\begin{tabular}{|c|c|c|c|c|}
\hline $\begin{array}{l}\text { Etiologies } \\
\text { ALAT }\end{array}$ & $\begin{array}{c}1.5 \mathrm{~N}<\text { ALAT } \\
<10 \mathrm{~N}\end{array}$ & $\begin{array}{c}\text { ALAT } \\
10 \mathrm{~N}-15 \mathrm{~N}\end{array}$ & $\begin{array}{c}\text { ALAT }>15 \\
\mathrm{~N}\end{array}$ & $\mathrm{p}$ \\
\hline Cirrhosis & $53-(34.2 \%)$ & & & $3 \times 10^{-5}$ \\
\hline $\begin{array}{l}\text { Hepatocellullary } \\
\text { carcinoma }\end{array}$ & $40-(25.8 \%)$ & & & $8 \times 10^{-4}$ \\
\hline Viral hepatitis & $20-(12.9 \%)$ & $03-(27.3 \%)$ & $15-(45.6 \%)$ & $6 \times 10^{-5}$ \\
\hline $\begin{array}{l}\text { Obstruction of } \\
\text { the bile ducts }\end{array}$ & $02-(1.3 \%)$ & $04-(36.4 \%)$ & $09-(27.3 \%)$ & $10^{-8}$ \\
\hline $\begin{array}{l}\text { Drud-induced } \\
\text { hepatitis }\end{array}$ & $02-(1.3 \%)$ & $02-(18.2 \%)$ & $06-(18.2 \%)$ & $3 \times 10^{-5}$ \\
\hline AIDS & $9-(5.8 \%)$ & & & 0.262 \\
\hline Malaria & $02-(1.3 \%)$ & $01-(9.1 \%)$ & $03-(9.1 \%)$ & 0.0282 \\
\hline Fatty liver & $6-(3.9 \%)$ & & & 0.4155 \\
\hline $\begin{array}{l}\text { Peritoneal } \\
\text { tuberculosis }\end{array}$ & $7-(4.5 \%)$ & & & 0.357 \\
\hline Liver metastases & $3-(1.9 \%)$ & & & 0.648 \\
\hline Hépatic abscess & $5-(3.2 \%)$ & & & 0.4828 \\
\hline Alcoholic hepatitis & $3-(1.9 \%)$ & & & 0.648 \\
\hline Help syndrome & & $01-(9.1 \%)$ & & - \\
\hline Hyperthyroidism & $1-(0.6 \%)$ & & & - \\
\hline Heart liver & $2-(1.3 \%)$ & & & - \\
\hline Total & 155 & 11 & 33 & \\
\hline
\end{tabular}

\section{Discussion}

Limitations: In our study, some investigations necessary for etiological diagnosis could not be carried out because of the lack of financial resources and our traditional beliefs. However, the results obtained allowed a reasonable analysis of the characteristics of hepatic cytolysis in our study center. This study reported a frequency of cytolysis of $7.1 \%$ in 2800 patients who consulted during the study period. This result is superior to those of Friedman et al., of Capron and al and of Driss et al. [3] [4] [5] who reported $0.5 \%, 5 \%$ and $4.8 \%$ respectively. This difference could be explained by the high frequency of viral hepatitis and its complications (cirrhosis, HCC) in our context. The mean age of the patients was $44.06 \pm 16.4$ years, lower than that reported by Hachicha et al. [6] which was 55 years in a study on the contribution of PBF in the etiological diagnosis of cytolysis and/or unexplained cholestasis. The sex ratio was 1.73 in our study, which was contrary to that found by Hachicha et al. [6] which was 0.44 . This difference could be explained by the frequency of chronic HBV carriage in humans in our 
context [7]. The predominance of cytolysis in farmers and housewives were reported by our study. This could be explained by the promiscuity in these social strata which would favor the transmission of HBV. Asthenia and anorexia were the signs that prompted the consultation, thus confirming Bragança's result [8]. The physical signs were dominated by jaundice, hepatomegaly, ascites in our study. Hachicha et al. [6] reported a predominance of hepatosplenomegaly, jaundice, pruritus and gastrointestinal bleeding. HBsAg and anti-HCV Ab were found in $40.2 \%$ and $9 \%$ of our patients, respectively. This frequency of HBV infection in our context is reported by a previous study which found at least one serum marker of $\mathrm{HBV}$ in $60.2 \%$ of patients with $\mathrm{HCC}$ [9]. A study recent report has reported the prevalence of HBs Antigen to be $14.7 \%$ of the general population [7]. A recent study reported the prevalence of the HBs Antigen to $14.7 \%$ of the general population [7]. In the work Debonne et al. [10], after steatosis (52\%), chronic hepatitis with or without cirrhosis viral predominance $B$ is the second largest diagnostic framework (33\% of cases). This is confirmed by our study which found an elevation of transaminases $>1.5 \mathrm{~N}$ and $<10 \mathrm{~N}$ linked to HBV and $\mathrm{HCV}$ in $77.5 \%$ and $100 \%$ of cases, respectively. An aspect of chronic cytolysis was more frequent. The incidence of chronic cytolysis varied between $3 \%$ and $12 \%$ in the general population [11] [12] and 1 to 6 cases per year per million inhabitants in developed countries [13] [14] [15] [16] for the acute cytolysis. Viral hepatitis $B$, obstruction of the bile ducts, drug-induced hepatitis and malaria were significantly associated with acute cytolysis respectively $\mathrm{p}=6 \times 10^{-5}, 10^{-8}$, $3 \times 10^{-5}$ and 0.0282 . Potel et al. [17] in a study of acute hepatitis to emergencies report that viral hepatitis $B$ remains the main infectious cause of acute liver failure. Pateron Guyader et al. found that obstruction of the bile ducts were the second cause of acute cytolysis [1] [18]. Drug-induced hepatitis are the main causes of acute cytolytic the United States and Western Europe [17]. Cirrhosis and hepatocellular carcinoma were significantly associated with chronic cytolysis $\mathrm{p}=3 \times 10^{-5}$ and $8 \times 10^{-4}$. This result confirms that of Diallo [6] and Ouavene et al. [19] who found chronic cytolysis in 52\% and 68\% of cirrhotic patients, respectively. Otherwise, Aoudad found $10 \%$ of chronic cytolysis associated with hepatocellular carcinoma [20]. The greater representativeness of hepatocellular carcinoma in our study could be explained by delayed diagnosis of this condition [21], for which infection by HBV remains the main cause in our context [9].

\section{Conclusion}

Hepatic cytolysis has been little studied in Africa and particularly in Mali. This study was carried out with a view to providing information on this biological anomaly. The prevalence of cytolysis was $7.1 \%$ in our patients. The main reasons for consultation were physical asthenia and anorexia. Jaundice, hepatomegaly and ascites were the physical signs commonly found in patients. The main causes of acute cytolysis were viral hepatitis B, bile duct obstructions, drug-induced hepatitis and malaria, while chronic cytolysis was mainly tied to cirrhosis and 
hepatocellular carcinoma.

\section{Conflicts of Interest}

The authors declare no conflicts of interest regarding the publication of this paper.

\section{References}

[1] Guyader, D. (2018) Cytolyse aiguë. EMC-Hépatologie, 13, 1-6.

[2] Valla, D.C. (2003) Augmentation chronique et inexpliquée des transaminases. FMC Hépato-Gastro, 10, 257-263.

[3] Friedman, L.S., Dienstag, J.L. and Watkins, E. (1987) Elevation of Blood Donors with Elevated Serum Alanine Aminotransferase Levels. Annals of Internal Medicine, 107, 137-144. https://doi.org/10.7326/0003-4819-107-2-137

[4] Capron, J.P. (1989) Augmentation modérée et prolongée de l'activité sérique des transaminases. Conduite à tenir. La Presse Médicale, 18, 913-916.

[5] Driss, F., Boboc, B., Zarski, J.P., Cals, M.J., Pol, S., Eme, D., et al. (1989) An Epidemiological and Clinical Study of Transaminase Level and Hepatitis B Antibodies in 1,100 Blood Donors. Vox Sanguinis, 57, 43-48. https://doi.org/10.1159/000460999

[6] Hachicha, S., Gdoura, H., Chtourou, L., Boudabous, M., Amouri, A., Mnif, L. and Tahri, N. (2018) Apport de la PBF dans le diagnostic étiologique de la cytolyse et/ou la cholestase chronique inexpliquée. Revue de Médecine Interne, 2, A209. https://doi.org/10.1016/j.revmed.2018.10.204

[7] Konaté, A., et al. (2019) Epidemiological and Serological Profile of Hepatitis B Virus in an Urban Area in Mali. Open Journal of Gastroenterology, 9, 158-163. https://doi.org/10.4236/ojgas.2019.98018

[8] Dos Santos Bragança, A. (2017) Elévation des tests hépatiques-Service de médecine de premier recours-DMCPRU-HUG-2017.

[9] Dicko, M.Y., Doumbia, K., Samaké, S.H., Coulibaly, K.M., Tounkara, M.C., Sanogo, S.D. and Sidibé (2018) Epidémiologie actuelle du carcinomehépatocellulaire au service d'hépato-gastroentérologie du CHU Gabriel Touré-Bamako. Médecine d Afrique Noire, 10, 498-502.

[10] Debonne, J.M., Guisset, M. and Klotz, F. (1992) Le syndrome de cytolyse hépatique chronique en Afrique noire. Médecine d Afrique Noire, 39, 644-665.

[11] Clark, J.M., Brancati, F.L. and Diehl, A.M. (2003) The Prevalence and Etiology of Elevated Amino-Transferase Levels in the United States. American Journal of Gastroenterology, 98, 960-967. https://doi.org/10.1111/j.1572-0241.2003.07486.x

[12] Pendino, G.M., Mariano, A., Surace, P., Caserta, C.A., Fiorillo, M.T., Amante, A., et al. (2005) Prevalence and Etiology of Altered Liver Tests: A Population-Based Survey in a Mediterranean Town. Hepatology, 41, 1151-1159. https://doi.org/10.1002/hep.20689

[13] Bernal, W., Auzinger, G., Dhawan, A. and Wendon, J. (2010) Acute Liver Failure. The Lancet, 376, 190-201. https://doi.org/10.1016/S0140-6736(10)60274-7

[14] Bower, W.A., Johns, M., Margolis, H.S., Williams, I.T. and Bell, B.P. (2007) Population Based Surveillance for Acute Liver Failure. American Journal of Gastroenterology, 102, 2459-2463. https://doi.org/10.1111/j.1572-0241.2007.01388.x

[15] Brandsaeter, B., Hockerstedt, K., Friman, S. and Ericzon, B.G. (2002) Fulminant Hepatic Failure: Outcome after Listing for Highly Urgent Liver Transplantation-12 
Years Experience in the Nordic Countries. Liver Transplantation, 8, 1055-1062. https://doi.org/10.1053/jlts.2002.35556

[16] Escorsell, A., Mas, A., de la Mata, M. and the Spanish Group for the Study of Acute (2007) Liver Failure. Acute Liver Failure in Spain: Analysis of 267 Cases. Liver Transplantation, 13, 1389-1395. https://doi.org/10.1002/lt.21119

[17] Potel, G., Batard, E., Le conte, P., Montassier, E., Goffinet, N., Berthier, F., et al. (2013) Hépatites aiguës aux urgences. Sfmu, 69, 1-5.

[18] Pateron, D., Legendre, N. and Debuc, E. (2009) Anomalies hépatiquesaux urgences. SAMU de France, 40, 436-442.

[19] Ouavene, J.O., Koffi, B., Mobima, T., Bekondji, C., Massengue, A. and Guenebem, K. (2013) Cirrhose du foie à l'hôpital de Bangui: Aspects épidémiologiques, cliniques, échographiques et problèmes de diagnostic. Thèse Med., Bangui, No. 203, 75 p.

[20] Aoudad, M. (2017) Le carcinome hépatocellulaire thèse. No. 52, Med., Maroc, 46 p.

[21] Salimou, K. (2012) Aspect échographique du CHC. No. 18M08, Thèse Med., Bamako, $98 \mathrm{p}$. 